\title{
PENGAWASAN TERHADAP APARATUR LEMBAGA KEJAKSAAN BERDASARKAN UNDANG-UNDANG NOMOR 5 TAHUN 2014 TENTANG APARATUR SIPIL NEGARA
}

\author{
Teguh Subroto \\ Email: teguhsubroto29@gmail.com \\ Pegawai Kejaksaan Tinggi Kepulauan Riau \\ Hartiwiningsih, Supanto \\ Email: hartiwi@yahoo.com, supanto.8787@gmail.com \\ Dosen Fakultas Hukum UNS Surakarta
}

\begin{abstract}
This article aims to examine the oversight system of the apparatus of the prosecutor institution before Law No. 5 of 2014 on State Civil Apparatus as well as the implications of Law No. 5 of 2014 on State Civil Apparatus on the authority of the prosecutor's office in the field of supervision. Through normative legal research or doctrinal law research, the result shows that the system of supervision of the apparatus of the prosecutor institution before Law No. 5 of 2014 on State Civil Apparatus is based on the division of internal control as the control within the prosecutor's and external organizations as a control outside the prosecutor's organization. Implemented by the Prosecutor Commission. With the enactment of Law Number 5 Year 2014 on the State Civil Apparatus (ASN) which regulates the authority of the State Civil Service Commission (CASN), overlaps with the supervision of the Attorney General of the Republic of Indonesia regulated in the Attorney General Regulation No. PER- 022/A/JA/03/2011 on the Implementation of Oversight of the Attorney of the Republic of Indonesia. The authority of KASN will clash with the Deputy Attorney General for Supervision in conducting inherent supervision and functional oversight.
\end{abstract}

Keywords: Attorney; Supervision; State Civil Apparatus.

\begin{abstract}
Abstrak
Artikel ini bertujuan untuk mengkaji sistem pengawasan terhadap aparatur lembaga kejaksaan sebelum Undang-Undang Nomor 5 tahun 2014 tentang Aparatur Sipil Negara serta implikasi Undang-Undang Nomor 5 tahun 2014 tentang Aparatur Sipil Negara terhadap kewenangan kejaksaan dalam bidang pengawasan. Melalui penelitian hukum normatif atau penelitian hukum doktrinal didapatkan hasil, bahwa sistem pengawasan terhadap aparatur lembaga kejaksaan sebelum Undang-Undang Nomor 5 tahun 2014 tentang Aparatur Sipil Negara didasarkan oleh pembagian pengawasan internal sebagai kontrol di dalam organisasi kejaksaan dan eksternal sebagai kontrol di luar organisasi kejaksaan yang dilaksanakan Komisi Kejaksaan. Dengan berlakunya Undang-Undang Nomor 5 Tahun 2014 tentang Aparatur Sipil Negara (ASN) yang mengatur kewenangan Komisi Aparatur Sipil Negara (KASN), menimbulkan tumpang tindih dengan penyelenggaraan pengawasan di lingkungan Kejaksaan Republik Indonesia yang diatur dalam Peraturan Jaksa Agung Republik Indonesia Nomor: PER-022/A/JA/03/2011 tentang Penyelenggaraan Pengawasan Kejaksaan Republik Indonesia. Kewenangan KASN akan berbenturan dengan Jaksa Agung Muda Pengawasan dalam melaksanakan pengawasan melekat dan pengawasan fungsional.
\end{abstract}

Kata Kunci: Jaksa; Pengawasan; Aparatur Sipil Negara. 


\section{A. Pendahuluan}

Lahirnya Undang-Undang Nomor 5 Tahun 2014 tentang Aparatur Sipil Negara (UU ASN) ternyata memberi masalah baru bagi Kejaksaan. Dengan berlakunya UU ASN, memiliki konsekuensi yang tidak menguntungkan bagi Korps Adhyaksa. Sebagai profesi penegak hukum, Jaksa akan menjadi profesi yang terkekang dengan berbagai birokrasi. Apabila profesi Jaksa tetap dimasukkan dalam UU ASN, maka penempatan Jaksa di Komisi Pemberantasan Korupsi (KPK) akan terancam berhenti.

Pasal 20 UU ASN menyatakan bahwa:

(1) Jabatan ASN diisi dari Pegawai ASN.

(2) Jabatan ASN tertentu dapat diisi dari:

a. Prajurit Tentara Nasional Indonesia; dan

b. Anggota Kepolisian Negara Republik Indonesia.

(3) Pengisian Jabatan ASN tertentu yang berasal dari prajurit Tentara Nasional Indonesia dan anggota Kepolisian Negara Republik Indonesia sebagaimana dimaksud pada ayat (2) dilaksanakan pada Instansi Pusat sebagaimana diatur dalam Undang-Undang tentang Tentara Nasional Indonesia dan UndangUndang tentang Kepolisian Negara Republik Indonesia.

(4) Ketentuan lebih lanjut mengenai Jabatan ASN tertentu yang berasal dari prajurit Tentara Nasional Indonesia dan anggota Kepolisian Negara Republik Indonesia dan tata cara pengisian jabatan ASN sebagaimana dimaksud pada ayat (3) diatur dengan Peraturan Pemerintah.

Dalam pasal tersebut di atas, tidak mengatur mekanisme penempatan Jaksa di lembaga lain, yang ada hanya pengaturan untuk prajurit Tentara Nasional Indonesia (TNI) dan Anggota Kepolisian Republik Indonesia
(Polri). Padahal Jaksa pada kenyataannya juga ditempatkan dalam lembaga lain seperti KPK saat ini. Berdasarkan hal tersebut, maka KPK terancam kehilangan Jaksa Penuntut Umum (JPU) atas penerapan UU ASN. Hal ini karena undang-undang tersebut tidak mengatur mekanisme penempatan Jaksa di lembaga lain, yang ada hanya pengaturan untuk TNI dan Polri.

Selain itu Jaksa memiliki kode etik profesi yang punya sangat lengkap seperti: Kode Etik Organisasi dalam Keputusan Jaksa Agung R.I. (Kepja) Nomor: KEP-30/JA/03/1988 tentang Penyempurnaan Doktrin Kejaksaan Tri Krama Adhyaksa jo Kepja Nomor: KEP52/JA/08/1979 tentang Doktrin Kejaksaan Tri Krama Adhyaksa. Kemudian, Kode Etik Perilaku dalam Peraturan Jaksa Agung R.I. (Perja) Nomor: PER-067/A/JA/2007 tentang Kode Etik Perilaku Jaksa, serta Kode Etik Profesi dalam Perja Nomor: PER-066/A/ JA/7/2007 tentang Standar Minimum Profesi Jaksa. Hal inilah yang membedakan profesi Jaksa dengan profesi lainnya, maka akan menjadi rancu ketika diatur kode etik Aparatur Sipil Negara.

Lembaga Kejaksaan memiliki Majelis Kehormatan Jaksa yang diatur dalam Kepja Nomor: KEP-017/A/JA/01/2004 tentang Majelis Kehormatan Jaksa. Apabila Jaksa masuk dalam ruang lingkup pengaturan UU ASN, maka peran dan fungsi Majelis Kehormatan Jaksa otomatis akan hilang. Dalam Pasal 30 UU ASN menyatakan bahwa: KASN berfungsi mengawasi pelaksanaan norma dasar, kode etik dan kode perilaku ASN, serta penerapan Sistem Merit dalam kebijakan dan Manajemen ASN pada Instansi Pemerintah.

Berdasarkan pasal tersebut, maka Komisi Aparatur Sipil Negara (KASN) berfungsi sebagai pengawas pelaksanaan kode etik dan perilaku. Jika fungsi keduanya sama, maka Majelis Kehormatan Jaksa terancam 
keberadaannya. Hal ini akan menjadi tumpang tindih, ketika kedua lembaga tersebut mengeluarkan keputusan yang berbeda. Selain itu amanat Undang-Undang Nomor 16 Tahun 2004 tentang Kejaksaan Republik Indonesia (UU Kejaksaan) yang membentuk Komisi Kejaksaan R.I. (Komjak) turut memperkuat argumen untuk mengecualikan profesi Jaksa dari UU ASN. Apabila profesi Jaksa tetap masuk sebagai bagian dalam UU ASN, maka keberadaan Komjak haruslah dibubarkan.

Berdasarkan uraian tersebut di atas, maka dalam artikel ini dibahas bagaimanakah sistem pengawasan terhadap aparatur lembaga kejaksaan sebelum Undang-Undang Nomor 5 Tahun 2014 tentang Aparatur Sipil Negara, dan bagaimanakah implikasi Undang-Undang Nomor 5 Tahun 2014 tentang Aparatur Sipil Negara terhadap Kewenangan Kejaksaan dalam bidang Pengawasan?

\section{B. Metode Penelitian}

Jenis Penelitian ini adalah penelitian hukum normatif atau penelitian hukum doktrinal. Penelitian ini menggunakan pendekatan konseptual, menggunakan teknik analisis bahan hukum deduktif silogisme dengan menggunakan premis minor dan premis mayor dan penarikan kesimpulan. Penelitian ini menggunakan teknik analisis bahan hukum studi kepustakaan atau library research.

\section{Hasil Penelitian dan Pembahasan}

1. Sistem Pengawasan Terhadap Aparatur Lembaga Kejaksaan Sebelum UndangUndang Nomor 5 Tahun 2014 tentang Aparatur Sipil Negara

Berdasarkan hasil penelitian, dari kurun waktu Januari 2016 sampai Desember 2016, Kejaksaan Agung (Kejagung) telah menjatuhkan sanksi pada puluhan Jaksa nakal. Setidaknya terdapat beberapa Jaksa dan pejabat administrasi diberikan sanksi sebagai berikut:

\begin{tabular}{|l|l|c|c|}
\hline No. & Jenis Sanksi & $\begin{array}{c}|c| \\
\text { Penerima Saksi } \\
\text { Tata } \\
\text { Usaha }\end{array}$ & Jaksa \\
\hline 1. & Sanksi Ringan & 24 Orang & 37 Orang \\
\hline 2. & Sanksi Sedang & 18 Orang & 21 Orang \\
\hline 3. & Sanksi Berat & 32 Orang & 25 Orang \\
\hline
\end{tabular}

Sumber: Pusat Penerangan Hukum Kejagung 2016

Kinerja Kejagung, khususnya dalam bidang pembinaan maupun pengawasan masih harus ditingkatkan mengingat semakin kuatnya sorotan masyarakat kepada institusi kejaksaan. Jika tidak, maka kepercayaan masyarakat kepada korps Adhyaksa akan semakin luntur sehingga dapat menghambat upaya penegakkan hukum di Indonesia.

Pengawasan lembaga Kejaksaan sebagai subsistem Sistem Peradilan Pidana (SPP) sangat penting artinya sebagai rangkaian pengawasan secara menyeluruh terhadap sub-sub sistem yang lain dalam kerangka yang lebih luas dalam hubungannya untuk mencapai tujuan SPP dan penegakan hukum. Mardjono Reksodiputro lebih lanjut mengatakan:

"Keterkaitan antar sub-sistem satu dengan yang lainnya adalah seperti "bejana berhubungan" setiap masalah dalam salah satu subsistem (misal: Kejaksaan) akan menimbulkan dampak pada sub-sistem awal dan demikian selanjutnya terus menerus. Pada akhirnya tidak jelas mana yang merupakan sebab (awal) dan yang mana akibat (reaksi)." (Marjono Reksodiputro, 1999 : 89).

Ini tidak terlepas dengan adanya mekanisme kontrol terhadap sub-sub sistem dalam SPP termasuk lembaga kejaksaan. Berkaitan dengan hal 
tersebut pertanggungjawaban kejaksaan dapat dilihat dari dua sisi, pertama pertanggungjawaban institusi, dan kedua pertanggungjawaban personal. Sedangkan pengawasan terkait dengan pedoman organisasi, kebijakan, prosedur dan peraturan. Adanya (discretion) kebijakan kewenangan dan penggunaan wewenang dari aspek positif, justru merupakan saran acuan bagi aparatur kejaksaan di dalam menjalankan tugas dan wewenangnya secara bertanggungjawab. (Marwan Effendy, 28 Oktober 2004).

Berkenaan dengan hal tersebut Harkristuti Harkrisnowo mengatakan bahwa:

"Pengawasan merupakan salah satu pilar dalam manajemen yang baik, lemahnya pengawasan akan membawa dampak yang negatif pada seluruh produktivitas lembaga apapun. Sebagai pemegang kekuasaan untuk melalukan proses peradilan, kewenangan yang tanpa batas akan membahayakan publik. Oleh karenanya diperlukan mekanisme kontrol untuk mencegah atau paling tidak mereduksi adanya penyimpangan hukum dan penyalahgunaan kewenangan demi terjaminnya hak asasi manusia. Mekanisme kontrol yang diciptakan haruslah rasional, proporsional dan obyektif." (Harkristuti Harkrisnowo, 22 Agustus 2001).

Untuk dapat menjamin kinerja yang baik, dalam penyelenggaraan proses peradilan pidana oleh Kejaksaan mekanisme kontrol dapat dilakukan sebagai berikut:

1. Mekanisme kontrol internal, yang dapat dirumuskan dalam perundangundangan internal lembaga, yang mendorong agar: a. Sesama aparat menjaga kinerja kolega mereka; dan

b. Agar atasan meningkatkan kualitas produk aparat yang dipimpinnya, dengan memberikan penghargaan pada personel yang berprestasi, dan menjatuhkan sanksi dalam berbagai tingkatan, bagi mereka yang buruk performancenya;

2. Mekanisme kontrol eksternal, yang dapat dilakukan oleh lembaga penegak hukum antara lain maupun oleh publik :

a. Kontrol oleh lembaga lain dalam Sistem Peradilan Pidana. Kontrol ini harus secara tegas dirumuskan dalam perundang- undangannya sekaligus dengan sanksi yang diancamkan apabila personel atau lembaga tidak melaksanakan kewajibannya sesuai dengan due process of Law;

b. Kontrol oleh publik.

Untuk menegaskan bahwa partisipasi publik merupakan faktor pendorong profesionalisme Kejaksaan, maka perlu dirancang adanya mekanisme kontrol yang memberikan akses pada publik manakala kinerja lembaga ini mengabaikan ketentuan yang ada. Selain melalui pra peradilan, adanya lembaga yang melakukan pemantauan terhadap setiap lembaga akan sangat membantu. Melihat pentingnya lembaga semacam ini, maka perumusannya perlu dimasukkan dalam peraturan perundangundangan organik, untuk menjamin bahwa keberadaannya diperhatikan oleh Kejaksaan. (Harkristuti Harkrisnowo, 22 Agustus 2001). 
Mekanisme kontrol terhadap aparatur lembaga kejaksaan secara internal yaitu Jaksa Agung Muda Pengawasan (Jamwas), Majelis Kehormatan Jaksa, Kode Etik dan Eksaminasi perkara, sedangkan secara eksternal yaitu Komisi Kejaksaan dan Masyarakat. Di sisi yang lain, kontrol terhadap kejaksaan secara horizontal dilakukan oleh sub-sub sistem lain dalam SPP dan secara vertikal oleh atasan dengan bentuk pengawasan melekat dan pengawasan fungsional.

Tugas dan kewenangan Jamwas adalah: pertama, perumusan kebijaksanaan teknis pengawasan di lingkungan kejaksaan; kedua, perencanaan, pelaksanaan dari pengendalian pengamatan, penelitian, pengujian, penilaian, pemberian bimbingan, penertiban atas pelaksanaan tugas rutin dan pembangunan semua unsur kejaksaan terutama mengenai administrasi umum, proyek pembangunan, intelijen, tindak pidana umum, tindak pidana khusus, perdata dan tata usaha negara di lingkungan kejaksaan serta pengadministrasian; ketiga, pelaksanaan pengusutuan, pemeriksaan atas adanya laporan, pengaduan, penyimpangan, penyalahgunaan jabatan atau wewenang dan mengusulkan penindakan terhadap pegawai kejaksaan yang terbukti melalukan perbuatan tercela atau terbukti melakukan tindak pidana; keempat, pemantauan dalam rangka tindak lanjut pengawasan di lingkungan kejaksaan; kelima, pembinaan dan peningkatan kemampuan, keterampilan serta integritas kepribadian aparat pengawasan di lingkungan pengawasan pada umumnya; keenam, pembinaan kerja sama dan pelaksanaan koordinasi dengan aparat pengawasan fungsional instansi lain mengenai pelaksanaan pengawasan pada umumnya; ketujuh, pengamanan teknis atas pelaksanaan tugas dan wewenang kejaksaan di bidang pengawasan berdasarkan peraturan perundang-undangan dan kebijaksanaan yang ditetapkan oleh Jaksa Agung; dan kedelapan, pemberian saran pertimbangan kepada Jaksa Agung dan pelaksanaan tugas-tugas lain sesuai petunjuk Jaksa Agung.

Tugas dan fungsi Jamwas tersebut di atas merupakan salah satu bentuk pengawasan secara internal terhadap lembaga kejaksaan. Tugas dan fungsi tersebut pada dasarnya sudah cukup memadai sebagai syarat pengawasan. Apa yang menjadi tugas dan fungsi Jamwas merupakan usaha atau kegiatan mengetahui dan menilai kenyataan yang sebenarnya mengenai tugas dan kegiatan, apakah sesuai dengan semestinya atau tidak. Hal ini tentu saja berkenaan dengan tugas dan kegiatan kejaksaan sebagai lembaga penuntutan.

Dalam mengantisipasi kejadian penyimpangan terutama dugaan suap, menambah wewenang Jamwas yang diatur dalam Peraturan Jaksa Agung R.I. tentang Organisasi dan Tata Kerja Kejaksaan R.I., Peraturan Jaksa Agung Nomor: PER-022/A/JA/03/2011 tentang Penyelenggaraan Pengawasan Kejaksaan R.I., dan Juklak Jamwas tentang Teknis Penanganan Laporan Pengaduan dan Tata Kelola Administrasi Bidang Pengawasan. Paska lahirnya Peraturan Jaksa Agung Nomor: PER-022/ A/ JA/03/2011, Peraturan Jaksa Agung Nomor: PER-069/A/JA/07/2007 tentang Ketentuan-Ketentuan Penyelenggaraan Pengawasan Kejaksaan R.I. dicabut dan dinyatakan tidak berlaku. Bentuk pengawasan berdasarkan Peraturan Jaksa Agung Nomor: PER-022/A/JA/03/2011 tentang Penyelenggaraan Pengawasan Kejaksaan Republik Indonesia terdiri dari 
Pengawasan Melekat dan Pengawasan Fungsional.

UU Kejaksaan mengamanatkan pembentukan Majelis Kehormatan Jaksa, yang sebenarnya juga sudah diamanatkan oleh Undang Undang Kejaksaan sebelumnya yaitu dalam Pasal 13 ayat (3) Undang-Undang Nomor 5 Tahun 1991. Implementasi dari undangundang tersebut telah ada Keputusan Jaksa Agung Nomor: Kep-017/A/ J.A/01/2004 tentang Majelis Kehormatan Jaksa. Majelis Kehormatan Jaksa adalah satuan organisasi yang keanggotaannya ditetapkan oleh Jaksa Agung. Tugas dan fungsi Majelis Kehormatan Jaksa adalah memberikan pendapat tertulis kepada Jaksa Agung tentang Pemberhentian atau Pemberhentian Sementara Jaksa dari Jabatannya.

Pengawasan internal khusus dalam bidang kode etik, juga mengatur adanya Komisi Kode Etik Jaksa. Sesuai dengan
Surat Keputusan Pengurus Pusat Persatuan Jaksa Indonesia Nomor: KEP-001/ Persaja/ 03/1995 tentang Kode Etik Jaksa. Pengertian penegakkan Kode Etik Jaksa adalah merupakan rangkaian kegiatan Komisi Kode Etik Jaksa dalam mencari serta mengumpulkan data dan fakta guna membuat terang adanya dugaan pelanggaran atas Kode Etik Jaksa.

Selain pengawasan secara internal, kejaksaan juga mengenal pengawasan secara eksternal. Dalam Pasal 3 Perpres Nomor 18 Tahun 2005 tentang Komisi Kejaksaan, disebutkan bahwa Komisi Kejaksaan merupakan lembaga pemerintahan non-struktural yang dalam melaksanakan tugas dan wewenangnya bersifat mandiri, bebas dari pengaruh kekuasaan manapun.

Berdasarkan keseluruhan uraian di atas, maka dapat di gambarkan sistem pengawasan kejaksaan adalah sebagai berikut:

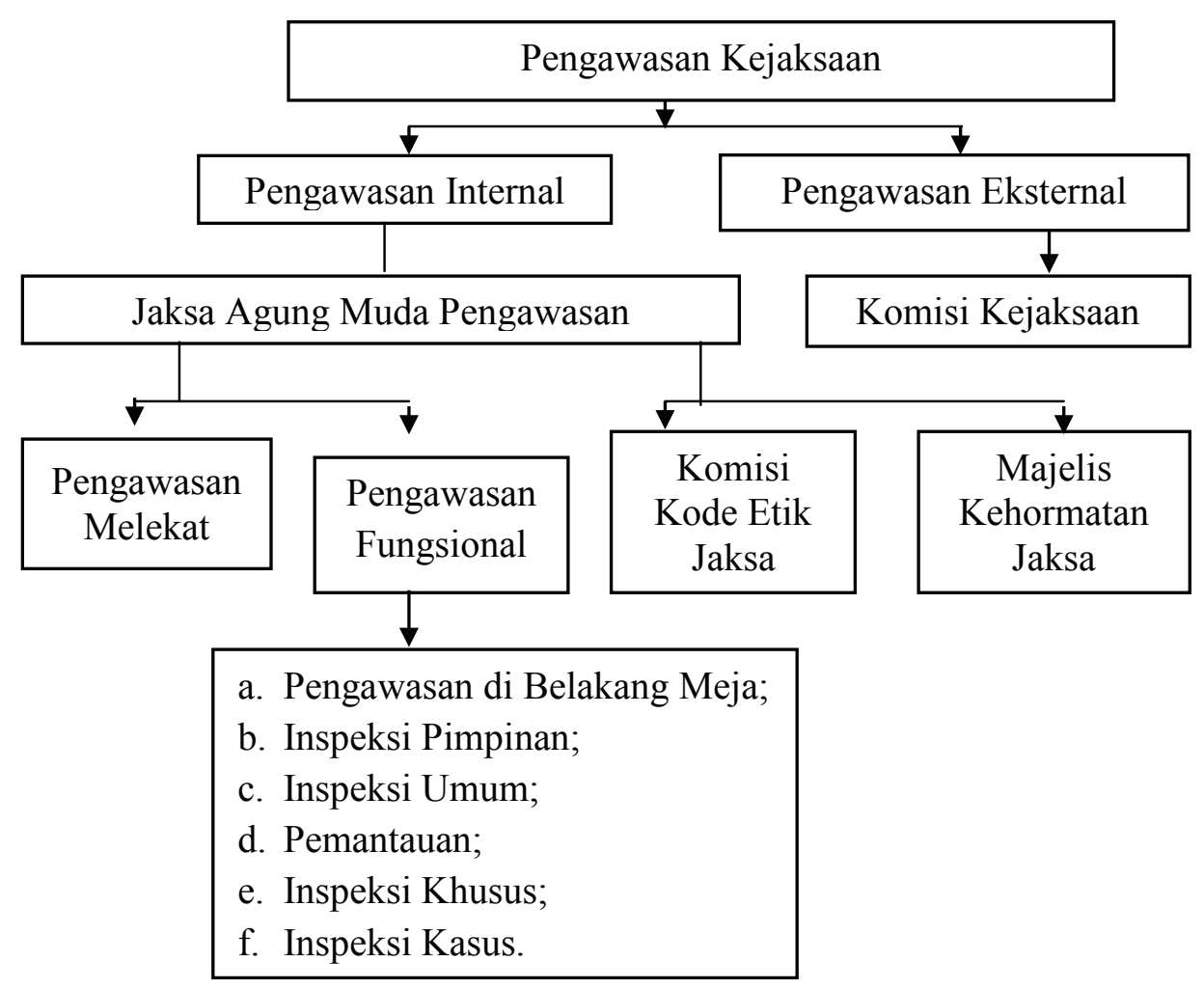


Berdasarkan keseluruhan uraian di atas, maka dapat disimpulkan bahwa, sistem pengawasan terhadap aparatur lembaga kejaksaan sebelum UU ASN didasarkan oleh pembagian pengawasan internal sebagai kontrol di dalam organisasi kejaksaan dan eksternal sebagai kontrol di luar organisasi kejaksaan yang dilaksanakan Komisi Kejaksaan. Pengawasan dilaksanakan oleh Jamwas. Konteks pengawasan Jamwas terbagi menjadi pengawasan umum dan pengawasan khusus. Pengawasan umum adalah pengawasan yang diatur dalam peraturan Penyelenggaraan Pengawasan Kejaksaan R.I. dengan dua bentuk pengawasan yaitu pengawasan melekat dan pengawasan fungsional. Sedangkan pengawasan internal khusus dilaksanakan oleh beberapa organ/pejabat kejaksaan khusus dengan materi yang juga khusus antara lain Komisi Kode Etik Jaksa dan Majelis Kehormatan Jaksa.

\section{Implikasi Undang-Undang Nomor} 5 Tahun 2014 Tentang Aparatur Sipil Negara Terhadap Kewenangan Kejaksaan Dalam Bidang Pengawasan

Sistem hukum di Indonesia yang berasal dari sistem hukum FrenchDutch civil law yang menganggap Jaksa bukan sebagai wakil rakyat dan tidak netral seperti hakim. Jaksa cenderung dipengaruhi pemerintah dan tidak lepas dari kebijakan pemerintah khususnya dalam penegakan hukum. Sejarah mencatat, ketika Belanda merdeka dari Prancis tahun 1813 timbul pertanyaan, apakah Jaksa merupakan bagian dari kekuasaan eksekutif atau bagian dari pengadilan (kekuasaan yudikatif atau bagian dari keduanya). Kedudukan Jaksa oleh Raja William selaku penuntut umum (public prosecutor) ditaruh di bawah pemerintah seperti pejabat publik lainnya dengan hierarki yang sama. Raja William memerintah Kerajaan Belanda dari tahun 1813 sampai 1840. Sebagai raja yang autokratik, Raja William ingin memastikan pengaruhnya pada pengadilan yang independen dengan menaruh Jaksa di bawah pemerintah (Darmono, 2013 : 50).

Hal tersebut juga masih diadopsi oleh Indonesia, hal ini di tegaskan dalam Pasal 2 ayat (1) UU Kejaksaan disebutkan bahwa: Kejaksaan Republik Indonesia yang selanjutnya dalam undang-undang ini disebut kejaksaan adalah lembaga pemerintah yang melaksanakan kekuasaan negara di bidang penuntutan serta kewenangan lain berdasarkan undangundang. Pertanggungjawaban Kejaksaan Republik Indonesia juga dilakukan langsung kepada Presiden selaku Kepala Pemerintahan.

Negara merupakan organ yang memiliki tujuan bersama. Dalam suatu negara menentukan setiap gerak dan tingkah laku, seperti lazimnya sebuah organisasi yang mempunyai tujuan tertentu. Sebagai suatu organisasi kekuasaan, ketentuan mengenai tujuan negara menjadi penting karena pada hakekatnya tujuan negara menentukan bagaimana cara mengatur dan menyusun negara yang bersangkutan (Victor Situmorang, 2007 : 18). Dalam rangka mencapai tujuan, negara menggunakan alat yang mempunyai tugas dan fungsi untuk mencapai tujuan, yang biasanya disebut dengan organ negara. Melalui individu yang terdapat dalam organ-organ inilah negara bertindak (Hans Kelsen, 2007 : 240). Organ-organ inilah yang disebut sebagai lembaga negara termasuk kejaksaan. 
Lembaga negara yang diatur dan dibentuk oleh Undang-Undang Dasar merupakan organ konstitusi, sedangkan yang dibentuk berdasarkan undangundang merupakan organ undang-undang, sementara yang hanya dibentuk karena Keputusan Presiden tentunya lebih rendah lagi tingkatan dan derajat perlakuan hukum terhadap pejabat yang duduk didalamnya. Demikian pula jika lembaga yang dimaksud dibentuk dan diberi kekuasaan berdasarkan Peraturan Daerah, tentu lebih rendah lagi tingkatannya. Kedudukan lembaga yang berbedabeda tingkatannya inilah yang ikut mempengaruhi kedudukan peraturan yang dikeluarkan oleh masing-masing lembaga tersebut. (Hans Kelsen, 2007 : 37).

Kejaksaan sebagai lembaga negara pemerintahan melaksanakan kekuasaan negara di bidang penuntutan harus bebas dari pengaruh kekuasaan pihak manapun, yakni yang dilaksanakan secara merdeka terlepas dari pengaruh kekuasaan pemerintah dan pengaruh kekuasaan lainnya. Oleh karena itu, sebagai lembaga negara individu-individu yang ada di dalamnya tidak lepas dari pengaturan aparatur sipil negara.

Dalam menjalankan suatu lembaga atau organisasi diperlukan fungsi-fungsi manajemen untuk mencapai tujuan organisasi, salah satu fungsi manajemen yaitu pengawasan. Pengawasan sebagai upaya kontrol birokrasi ataupun organisasi harus dilaksanakan dengan baik karena jika tidak dilaksanakan, cepat atau lambat akan mengakibatkan mati/ hancurnya suatu organisasi atau birokrasi itu sendiri. Pada lingkungan Kejaksaan, pengawasan internal dilakukan oleh Jamwas.

Dalam rangka merespon tuntutan dan sikap masyarakat guna meningkatkan dan menjaga kualitas kinerja dan perilaku jaksa dan pegawai di lingkungan Kejaksaan, selain pengawasan internal, maka berdasarkan amanat Pasal 38 UU Kejaksaan, Presiden Republik Indonesia secara atribusi memberikan kewenangan untuk membentuk suatu komisi independen yang berfungsi dalam rangka pengawasan eksternal, yang dikenal Komisi Kejaksaan. Pembentukan Komisi Kejaksaan merupakan suatu langkah pengawasan dalam rangka pelaksanaan pemerintahan yang bersih dan baik (good and clean government) di lingkungan kejaksaan, karena ini dinilai penting untuk mengawasi kinerja kejaksaan dan membuat rekomendasi kepada Presiden untuk menentukan kebijakannya di bidang hukum.

Sejalan dengan diterbitkannya UU ASN menggantikan Undang-Undang Nomor 8 Tahun 1974 jo Undang-Undang Nomor 43 Tahun 1999 tentang PokokPokok Kepegawaian, kejaksaan tidak disebutkan secara eksplisit sebagai lembaga yang dikecualikan. Pasal 25 UU ASN menyatakan bahwa:

(1) Presiden selaku pemegang kekuasaan pemerintahan merupakan pemegang kekuasaan tertinggi dalam kebijakan, pembinaan profesi, dan Manajemen ASN.

(2) Untuk menyelenggarakan kekuasaan sebagaimana dimaksud pada ayat (1), Presiden mendelegasikan sebagian kekuasaannya kepada:

1. Kementerian yang menyelenggarakan urusan pemerintahan di bidang pendayagunaan aparatur negara, berkaitan dengan kewenangan perumusan dan penetapan kebijakan, koordinasi dan sinkronisasi kebijakan, serta pengawasan atas pelaksanaan kebijakan ASN; 
2. KASN, berkaitan dengan kewenangan monitoring dan evaluasi pelaksanaan kebijakan dan Manajemen ASN untuk menjamin perwujudan Sistem Merit serta pengawasan terhadap penerapan asas serta kode etik dan kode perilaku ASN;

Dst

Dalam rangka penetapan kebijakan Manajemen ASN, dibentuk KASN yang mandiri dan bebas dari intervensi politik. Pembentukan KASN ini untuk monitoring dan evaluasi pelaksanaan kebijakan dan Manajemen ASN untuk menjamin perwujudan Sistem Merit serta pengawasan terhadap penerapan asas, kode etik dan kode perilaku ASN.

KASN beranggotakan 7 (tujuh) orang yang terdiri dari seorang ketua merangkap anggota, seorang wakil ketua merangkap anggota, dan 5 (lima) orang anggota. KASN dalam melaksanakan tugas dan wewenangnya dibantu oleh Asisten dan Pejabat Fungsional keahlian yang dibutuhkan. Selain itu KASN dibantu oleh sekretariat yang dipimpin oleh seorang kepala sekretariat. Ketua, wakil ketua, dan anggota KASN ditetapkan dan diangkat oleh Presiden selaku kepala pemerintahan untuk masa jabatan selama 5 (lima) tahun dan hanya dapat diperpanjang untuk 1 (satu) kali masa jabatan. Untuk menyalurkan aspirasi dalam rangka pembinaan dan pengembangan profesi ASN, Pegawai ASN berhimpun dalam wadah korps profesi Pegawai ASN Republik Indonesia yang bertujuan menjaga kode etik profesi dan standar pelayanan profesi ASN serta mewujudkan jiwa korps ASN sebagai perekat dan pemersatu bangsa.

Adanya lembaga pengawasan selain pengawasan internal yang dilakukan oleh Jamwas dan pengawasan eksternal yaitu Komisi Kejaksaan dan KASN, maka eksistensi Jamwas dikaitkan dengan keberadaan lembaga pengawasan oleh Komisi Kejaksaan dan KASN menjadi tumpang tindih, sehingga keberadaan pengawasan internal oleh Jamwas sebagai lembaga pengawasan pada lingkungan kejaksaan perlu diserasikan dan diharmonisasikan agar tidak terjadi tumpang tindih kewenangan.

Keterkaitan antara pengawasan internal di lingkungan kejaksaan dengan pengawasan eksternal yang dilakukan oleh Komisi Kejaksaan, diatur dalam Pasal 4 huruf e dan Pasal 5 ayat (2) Peraturan Presiden Nomor 18 Tahun 2011 tentang Komisi Kejaksaan R.I. serta adanya Nota Kesepahaman Jaksa Agung dengan Ketua Komisi Kejaksaan Nomor: KEP-009/A/JA/05/2011 dan Nomor: NK-001/KK/05/2011 tentang Mekanisme Kerja Antara Kejaksaan dengan Komisi Kejaksaan dalam Melaksanakan Pengawasan, Pemantauan dan Penilaian Atas Kinerja dan Perilaku Jaksa dan Pegawai Kejaksaan.

Berlakunya UU ASN yang mengatur kewenangan KASN menyebabkan struktur pengawasan menjadi berubah, yaitu sebagai berikut: 


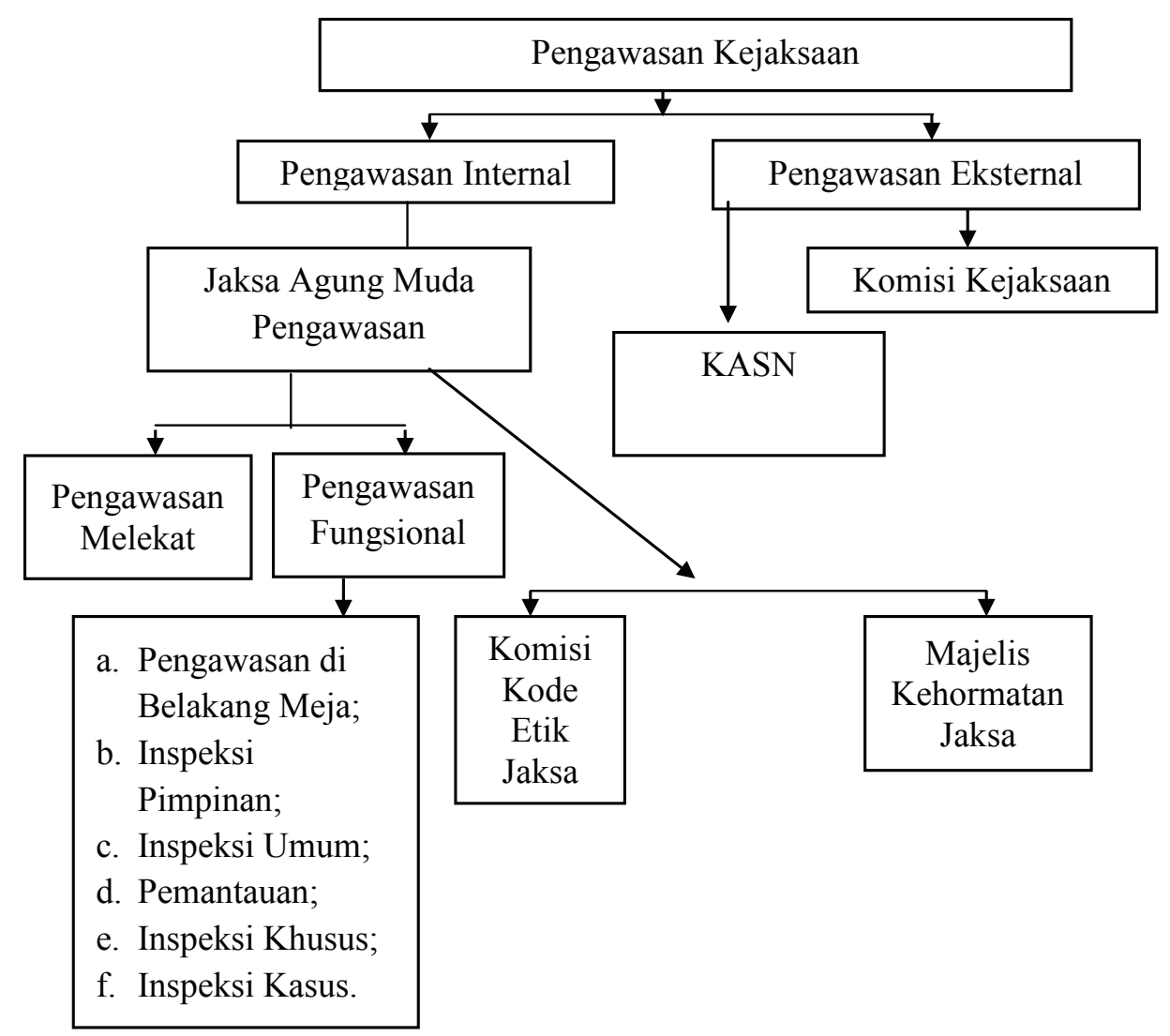

Berlakunya UU ASN yang mengatur kewenangan KASN, akan menimbulkan tumpang tindih dengan penyelenggaraan pengawasan di lingkungan Kejaksaan R.I. yang diatur dalam Peraturan Jaksa Agung R.I. Nomor: PER-022/A/JA/03/2011 tentang Penyelenggaraan Pengawasan Kejaksaan R.I., yang dilakukan dalam bentuk "Pengawasan Melekat" dan "Pengawasan Fungsional". Hal ini sejalan dengan ruang lingkup pengawasan berdasarkan Pasal 27 Peraturan Presiden Nomor 38 Tahun 2010 tentang Organisasi dan Tata Kerja Kejaksaan R.I. yang menyatakan bahwa pengawasan meliputi perencanaan, pelaksanaan dan pengendalian pelaksanaan pengawasan atas kinerja dan keuangan intern kejaksaan, serta pelaksanaan pengawasan untuk tujuan tertentu atas penugasan Jaksa Agung sesuai dengan ketentuan peraturan perundang-undangan. Tugas dan wewenang di bidang pengawasan dilaksanakan oleh Jamwas.

Dengan berlakunya UU ASN apabila dikaji secara obyektif, sesungguhnya belum mengakomodasi kekhususan karakteristik kelembagaan maupun profesi di kejaksaan seperti model birokrasi kelembagaan, model pembinaan kepegawaian, model akuntabilitas kinerja kelembagaan dan model pengawasan baik kelembagaan maupun profesi. Kekhususan karakteristik lembaga kejaksaan dapat dilihat dari landasan historis berdasarkan UUD 1945 dan Hukum Positif, kekhususan karakteristik kelembagaan dalam Sistem Ketatanegaraan, kekhususan karakteristik kelembagaan sebagai Penegak Hukum dalam Sistem Peadilan Pidana, sebagai Jaksa Pengacara Negara, kekhususan karakteristik kewenangan Jaksa dalam kaitannya dengan Hubungan Antar 
Lembaga maupun Hubungan Antar Negara, kekhususan karakteristik Profesi Jaksa, kekhususan karakteristik Jaksa Agung sebagai Penuntut Umum Tertinggi dan kekhususan lainnya.

Mekanisme pengawasan di kejaksaan dilakukan melalui pengawasan melekat dan pengawasan fungsional. Pengawasan melekat dilaksanakan oleh pimpinan satuan kerja terhadap bawahannya, sedangkan pengawasan fungsional pada umumnya dilakukan melalui pemeriksaan surat-surat (baik laporan pengawasan dari satuan kerja di kejaksaan maupun pengaduan masyarakat), dan inspeksi langsung ke berbagai unit kejaksaan di tingkat pusat dan daerah. Dengan terbentuknya Komisi Kejaksaan, maka ada keterkaitan/korelasi Komisi Kejaksaan dengan pengawasan internal kejaksaan yaitu Komisi Kejaksaan dapat melakukan pemeriksaan terhadap dugaan pelanggaran peraturan kedinasan Kejaksaan serta sikap perilaku jaksa dan pegawai kejaksaan apabila Komisi Kejaksaan mengambil alih pemeriksaan yang telah dilaksanakan oleh aparat pengawasan internal yang dianggap berlarut-larut, atau hasil pemeriksaan dinilai tidak sesuai dengan kesalahan yang dilakukan oleh jaksa atau pegawai kejaksaan atau apabila terjadi kolusi dalam pemeriksaan oleh aparat pengawasan internal.

Dengan berlakunya UU ASN yang mengatur kewenangan KASN, maka akan menimbulkan tumpang tindih dengan penyelenggaraan pengawasan di lingkungan kejaksaan karena pengawasan internal kejaksaan telah diatur secara rinci dalam Peraturan Jaksa Agung, dan Peraturan Presiden Nomor 38 Tahun 2010 tentang Organisasi dan Tata Kerja Kejaksaan R.I. Disamping itu UU ASN secara umum belum mengakomodir kekhususan karakteristik kelembagaan maupun profesi di kejaksaan, sedangkan Komisi Kejaksaan mempunyai korelasi dengan pengawasan internal kejaksaan sebagaimana diatur dalam Peraturan Presiden Nomor 18 Tahun 2011 tentang Komisi Kejaksaan R.I. dalam melaksanakan pengawasan, pemantauan dan penilaian atas kinerja dan perilaku Jaksa dan pegawai kejaksaan.

\section{Simpulan}

1. Sistem pengawasan terhadap aparatur lembaga kejaksaan sebelum UU ASN di dasarkan oleh pembagian pengawasan internal sebagai kontrol di dalam organisasi kejaksaan dan eksternal sebagai kontrol di luar organisasi kejaksaan yang dilaksanakan Komisi Kejaksaan. Pengawasan dilaksanakan oleh Jamwas. Konteks pengawasan Jamwas terbagi menjadi pengawasan umum dan pengawasan khusus. Pengawasan umum adalah pengawasan yang diatur dalam peraturan Penyelenggaraan Pengawasan Kejaksaan R.I. dengan dua bentuk pengawasan yaitu pengawasan melekat dan pengawasan fungsional. Sedangkan pengawasan internal khusus dilaksanakan oleh beberapa organ/pejabat kejaksaan khusus dengan materi yang juga khusus antara lain Komisi Kode Etik Jaksa dan Majelis Kehormatan Jaksa.

2. Berlakunya UU ASN yang mengatur kewenangan KASN, menimbulkan tumpang tindih dengan penyelenggaraan pengawasan di lingkungan kejaksaan yang diatur dalam Peraturan Jaksa Agung Nomor: PER-022/A/ JA/03/2011 tentang Penyelenggaraan Pengawasan Kejaksaan R.I. Kewenangan KASN akan berbenturan dengan Jamwas dalam melaksanakan pengawasan melekat dan pengawasan fungsional. 


\section{E. Saran}

1. Untuk menguatkan eksistensi di Bidang Pengawasan Internal Kejaksaan, maka diperlukan lembaga pengawasan internal kejaksaan dan Komisi Kejaksaan yang profesional dalam bertindak dan mempunyai integritas moral yang tinggi dan konsisten dalam memperjuangkan cita-cita penegakan hukum dan faktor subyektivitas sedapat mungkin harus dihilangkan.

2. Diperlukan koordinasi yang intensif antara aparat pengawasan internal kejaksaan dengan Komisi Kejaksaan agar tercipta sinergi dalam melaksanakan tugasnya.

3. Diperlukan Nota Kesepahaman antara Jamwas dengan KASN terkait penyelenggaraan pengawasan di lingkungan Kejaksaan Agung R.I., sehubungan dengan diberlakukannya Undang-Undang Nomor 5 Tahun 2014 tentang Aparatur Sipil Negara.

\section{F. Daftar Pustaka}

Darmono. 2013. Penyampingan Perkara Pidana Seponering Dalam Penegakan Hukum (Studi Kasus Ketetapan Mengenyampingkan Perkara Demi Kepentingan Umum Atas Nama Dr. Bibit Samad Riyanto dan Chandra M. Hamzah). Jakarta : Solusi Publishing.
Hans Kelsen. 2007. Teori Umum Hukum dan Negara. alih bahasa oleh Somardi. Jakarta : Bee Media Indonesia.

Harkristuti Harkrisnowo. 2001. "Membangun Strategi kinerja Kejaksaan bagi peningkatan Produktivitas, Profesionalisme, dan Akuntabilitas Publik: Suatu usulan pemikiran", Makalah disampaikan dalam rangka seminar mewujudkan supremasi hukum, Jakarta : Puslitbang Kejagung.

Mardjono Reksodiputro. 1999. Hak Asasi Manusia dan Sistem Peradilan Pidana. Jakarta: Pusat Pelayanan Keadilan dan Pengabdian Hukum (d/h Lembaga Kriminologi) dan UI Press.

Marwan Effendy. 2004. "Akuntabilitas Kejaksaan dan Komisi Pengawas". Makalah. Jakarta, 28 Oktober 2004.

Peter Mahmud Marzuki. 2005. Penelitian Hukum. Jakarta : Kencana Prenada Media Group,.

Soerjono Soekanto dan Sri Mamuji. 2003. Penelitian Hukum Normatif. Jakarta : Raja Grafindo Persada.

Victor Situmorang. 2007. Intisari Ilmu Negara. Jakarta : Bina Aksara. 